\title{
Pemanfaatan Penyuluhan Dengan Media Audiovisual, Untuk Meningkatkan Pengetahuan Remaja Tentang Infeksi Menular Seksual
}

\author{
Rosy Feratama ${ }^{1 *}$, Esti Nugraheny ${ }^{2 *}$ \\ ${ }^{1}$ Stikes Guna Bangsa, J1 Padjajaran, Condongcatur, Depok, Sleman Indonesia \\ ${ }^{2}$ Poltekkes Ummi Khasanah, Jl Pemuda Gandekan Bantul DIY \\ * rosyferatama1990@gmail.com, nugraheny.esti@gmail.com
}

\section{ARTICLE INFO}

\section{Article history:}

Received May 03, 2021

Accepted July 22, 2021

Published July 23, 2021

\section{Kata Kunci:}

Audiovisual

Pengetahuan

Remaja

Infeksi Menular Seksual

Key words:

Audiovisual

Knowledge

Adolescents

Sexual Transmitted Disease

DOI:

https://10.48092/jik.v7i2.134

\section{ABSTRAK}

Latar Belakang: Lebih dari satu juta orang terinfeksi penyakit menular seksual setiap hari dan diperkirakan 499 juta kasus Infeksi Menular Seksual (IMS) terjadi setiap tahun. Kelompok remaja dan dewasa muda (usia 15-24 tahun) merupakan kelompok umur yang beresiko paling tinggi untuk tertular IMS. Salah satu upaya pencegahan IMS pada remaja adalah dengan memberikan penyuluhan mengenai IMS. Penelitian ini bertujuan untuk mengetahui pengaruh penyuluhan dengan media audiovisual dibandingkan dengan media leaflet terhadap pengetahuan remaja tentang infeksi menular seksual. Metode: Penelitian ini merupakan quasi eskperimen dengan pre post test with control group design. Populasi kelompok eksperimen (audiovisual) 244 dan pada kelompok kontrol (leaflet) 381. Sampel diambil dengan menggunakan teknik proportional random sampling pada kelompok eksperimen 77 responden, pada kelompok kontrol 86 responden. Analisis data menggunakan $t$-test. Hasil: Peningkatan pengetahuan pada kelompok eksperimen lebih besar dibandingkan kelompok kontrol (40,05 $\pm 2,715$ VS $37,11 \pm 5,494$, t-hit $=4,401$ p-value $=0,000$ ). Kesimpulan: Pemberian penyuluhan dengan media audiovisual dan leaflet berpengaruh terhadap peningkatan pengetahuan remaja, namun audiovisual lebih berpengaruh dibanding lealfet.

\section{ABSTRACT}

Effect of Husband Support Related to Endorphin Massage on Breast Milk Production in Postpartum

Background: More than one million people are infected with sexually transmitted diseases every day and an estimated 499 million cases of Sexually Transmitted Infections (STIs) occur each year. Adolescents and young adults (aged 15-24 years) are the age group at the highest risk for contracting STIs. One of the efforts to prevent STIs in adolescents is to provide counseling about STIs. This study aims to determine the effect of counseling with audiovisual media compared to leaflet media on adolescent knowledge about sexually transmitted infection. Methods: This research is quasi-experimental with pre-post test with control group design. The population of the experimental group (audiovisual) is 244 , the sample is 77 respondents. The population in the control group (leaflet) is 381, the sample is 86 respondents. Samples were taken using proportional random sampling technique. Data analysis used t-test. Results: The increase of knowledge in the experimental group was greater than the control group $(40.05 \pm 2.715$ VS $37.11 \pm 5.494, \mathrm{t}$ hit=4.401 p-value=0.000). Conclusion: The provision of counseling using audiovisual media and leaflets has an effect on increasing adolescent knowledge, but audiovisuals are more influential than leaflets.

This open access article is under the CC-BY-SA license. 


\section{PENDAHULUAN}

Remaja dalam masa perkembangannya mengalami banyak perubahan, baik secara biologis, psikologis maupun kognitif. Pada umumnya, remaja lebih cepat mengalami pematangan fisik dibandingkan proses pematangan kejiwaan atau psikososial. Remaja seringkali kekurangan informasi dasar mengenai kesehatan reproduksi, dan memiliki keterbatasan dalam mengakses pelayanan kesehatan reproduksi yang terjamin kerahasiaannya (Rahayu, Suciawati, \& Indrayani, 2021). Kelompok remaja dan dewasa muda (usia 15-24 tahun) merupakan kelompok umur yang beresiko paling tinggi untuk tertular penyakit menular seksual (PMS). Tiga juta kasus baru tiap tahun terjadi pada remaja. Menurut World Health Organization (WHO), remaja memiliki persentase tertinggi pada virus ini dibanding kelompok umur lainnya. Satu dari 20 remaja tertular PMS setiap tahunnya, sementara hampir separuh kasus Human Infection Virus (HIV) baru berusia di bawah 25 tahun. PMS merupakan penyakit yang dapat ditularkan melalui kontak seksual seperti sering melakukan hubungan seksual dengan berganti-ganti pasangan (multipartner) dan melakukan hubungan seksual tanpa pengaman (kondom) (Mamarodia, Kandou \& Suling, 2017).

Infeksi Menular Seksual (IMS) merupakan penyakit yang masih menjadi masalah kesehatan utama di seluruh dunia. Lebih dari satu juta orang terinfeksi penyakit menular seksual setiap hari. Diperkirakan 499 juta kasus IMS (gonore, klamidia, sifilis dan trikomoniasis) terjadi setiap tahun disamping 536 juta orang diperkirakan hidup dengan herpes simplex virus tipe 2 (HSV-2). Sekitar 291 juta wanita memiliki human papilloma virus (HPV) (Kemenkes RI, 2017). Penyakit menular seksual memiliki dampak besar pada kesehatan seksual dan reproduksi seperti kematian janin dan bayi baru lahir. Sifilis dalam kehamilan menyebabkan 305.000 janin dan kematian neonatal, 215.000 bayi mengalami peningkatan risiko kematian akibat prematuritas, berat badan lahir rendah atau penyakit bawaan setiap tahun. IMS seperti gonore dan klamidia merupakan penyebab dari infertilitas, infeksi genital yang tidak diobati dapat menjadi penyebab sampai $85 \%$ dari infertilitas dan HIV pada wanita (Mamarodia, Kandou \& Suling, 2017).

Di Indonesia, berdasarkan Laporan Survei Terpadu dan Biologis Perilaku (STBP) oleh Kemenkes, (2012), prevalensi penyakit menular seksual (PMS) pada tahun 2011 untuk infeksi gonore dan klamidia adalah sebesar $179 \%$ dan sifilis sebesar $44 \%$. Pada kasus Human immu nodeficiency virus (HIV) dan Acquired immunodeficiency syndrome (AIDS) selama delapan tahun terakhir mulai dari tahun 2005 - 2012 menunjukkan adanya peningkatan. Kasus baru infeksi HIV meningkat dari 859 kasus pada 2005 menjadi 21.511 kasus di tahun 2012. Sedangkan kasus baru AIDS meningkat dari 2.639 kasus pada tahun 2005 menjadi 5.686 kasus pada tahun 2012 (Rahmi \& Gustini, 2015).

Data Survei Kesehatan Reproduksi Remaja Indonesia terakhir dari Badan Koordinasi Keluarga Berencana Nasional (BKKBN) pada tahun 2014 menyebutkan sebanyak 5.912 wanita di umur 15 - 19 tahun secara nasional pernah melakukan hubungan seksual. Sedangkan pria di usia yang sama berjumlah 6.578, atau $3,7 \%$ pernah melakukan hubungan seks. Tidak adanya mata pelajaran yang secara khusus yang mengajarkan dan memberikan informasi bagi murid SMA, juga menjadi salah satu penyebab tingginya angka kejadian penyakit menular seksual di kalangan remaja. Hal ini disebabkan masih kurangnya penyuluhan yang dilakukan oleh pemerintah dan badanbadan kesehatan lainnya (Rahmi \& Gustini, 2015).

Selain angka yang relatif tinggi, IMS dapat menimbulkan banyak dampak negatif baik dari segi fisik, psikososial, maupun finansial. Ketika seseorang terkena IMS akan terjadi perubahan fisik yang bisa mengganggu fisiologisnya. Misalnya saja, penyakit gonore bisa mengakibatkan kemandulan pada laki- laki maupun perempuan bila tidak ditangani dengan segera, bahkan bisa sampai menyebabkan kematian. Dampak psikososial dapat menimpa penderita maupun keluarga. Penderita IMS kebanyakan merasa malu untuk memberitahukan penyakitnya kepada orang terdekat. Hal ini dikarenakan penyakit ini masih memiliki stigma negatif di masyarakat. Lebih lanjut, beberapa IMS (seperti HIV, klamidia, gonore, dan sifilis) bisa berdampak negatif ataupun menular kepada bayi yang dikandung sang ibu. Selain dampak negatif secara fisik dan psikososial bagi penderita maupun keluarga, IMS juga membutuhkan biaya yang banyak baik untuk pengobatan (Pangaribuan \& Mardiah, 2018).

Latar belakang penelitian ini adalah permasalahan remaja yang berkaitan dengan kesehatan reproduksi yang semuanya berakar dari kurangnya informasi, pemahaman, dan kesadaran untuk mencapai keadaan sehat secara reproduksi. Banyak remaja yang menunjukkan perilaku yang positif dan berprestasi diberbagai bidang, namun, banyak juga dari mereka yang berperilaku negatif seperti merokok, penggunaan napza, tawuran, adanya tindakan aborsi, seks bebas yang dapat menyebabkan kehamilan yang tidak diinginkan dan penyakit menular lainnya. Untuk itu diperlukan pemahaman mengenai pemeliharaan kebersihan alat reproduksi, proses-proses reproduksi serta dampak dari perilaku yang tidak bertanggung jawab seperti kehamilan yang tidak diinginkan, aborsi, dan penyakit menular seksual lainnya yang sampai saat ini belum dapat untuk dipecahkan (Aritonang, 2015).

Upaya peningkatan pengetahuan pada remaja memerlukan suatu media pembelajaran yang dapat menggambarkan konsep fisik secara nyata. Salah satu media yang dapat di gunakaan adalah video. Video merupakan media audio visual yang dapat mengungkapkan objek dan peristiwa seperti keadaan 
sesungguhnya. Melalui media video, siswa mampu memahami pesan pembelajaran secara lebih bermakna sehingga informasi yang disampaikan melalui video tersebut dapat dipahami secara utuh (Meidiana, Simbolon \& Wahyudi, 2018).

\section{METODE}

Jenis penelitian ini adalah quasi eskperimen dengan pre post test with control group design. Tempat penelitian di SMAN 1 Gamping Sleman DIY. Populasi kelompok eksperimen 244, sampel 77 responden. Populasi pada kelompok kontrol 381, sampel 86 responden. Pengambilan sampel dalam penelitian ini adalah dengan menggunakan teknik proportional random sampling. Instrumen penelitian adalah media audiovisual, leaflet dan kuesioner. Prasyarat analisis menggunakan uji normalitas kolmogrov-smirnov dan uji hipotesis menggunakan paired sample t-test dan independent sample t-test.

\section{HASIL DAN PEMBAHASAN}

\section{Karakteristik Responden}

Tabel 1. Karakteristik Responden

\begin{tabular}{|c|c|c|c|c|c|c|}
\hline \multirow[t]{2}{*}{ Karakteristi } & & \multicolumn{2}{|c|}{ Kontrol } & \multicolumn{2}{|c|}{ Eksperimen } & \multirow[b]{2}{*}{$p$-value } \\
\hline & & $\mathrm{N}$ & $\%$ & $\mathrm{~N}$ & $\%$ & \\
\hline \multirow{3}{*}{ Umur } & 14 Tahun & 3 & 3.5 & 2 & 2.6 & \multirow{3}{*}{0,985} \\
\hline & 15 Tahun & 40 & 46.5 & 35 & 45.5 & \\
\hline & 16 Tahun & 43 & 50.0 & 40 & 51.9 & \\
\hline \multirow[t]{2}{*}{$\begin{array}{l}\text { Jenis } \\
\text { Kelamin }\end{array}$} & Laki-Laki & 36 & 41.9 & 29 & 37.7 & \multirow[t]{2}{*}{0,391} \\
\hline & Perempuan & 50 & 58.1 & 48 & 62.3 & \\
\hline \multirow{4}{*}{$\begin{array}{l}\text { Pengaruh } \\
\text { Orang Lain }\end{array}$} & Tidak & 29 & 33.7 & 25 & 32.5 & \multirow{4}{*}{0,203} \\
\hline & Tenaga & 19 & 22.1 & 23 & 29.9 & \\
\hline & Kesehatan & & & & & \\
\hline & Teman & 38 & 44.2 & 29 & 37.7 & \\
\hline \multirow{3}{*}{$\begin{array}{l}\text { Media } \\
\text { Massa }\end{array}$} & Tidak & 27 & 31.4 & 25 & 32.5 & \multirow{3}{*}{0,730} \\
\hline & Majalah/Koran & 15 & 17.4 & 16 & 20.8 & \\
\hline & $\begin{array}{l}\text { Handphone/Medi } \\
\text { a Sosial }\end{array}$ & 44 & 51.2 & 36 & 46.8 & \\
\hline
\end{tabular}

Berdasarkan tabel 1 karakterisitik pada kelompok eksperimen dan kelompok kontrol didapatkan sebagian besar berumur 16 tahun, berjenis kelamin perempuan, sebagian besar mendapatkan informasi kesehatan dari teman dan dari handphone/media social. Berdasarkan hasil dari $\mathrm{p}$ value untuk karakteristik tersebut dapat disimpulkan bahwa tidak ada perbedaan proporsi umur antara kelompok eksperimen dan kelompok control, tidak ada perbedaan proporsi jenis kelamin antara kelompok eksperimen dan kelompok control, dan tidak ada perbedaan proporsi pengaruh informasi antara kelompok eksperimen dan kelompok.

2. Analisis Paired Sampel T-Test Pengetahuan Remaja Tentang IMS

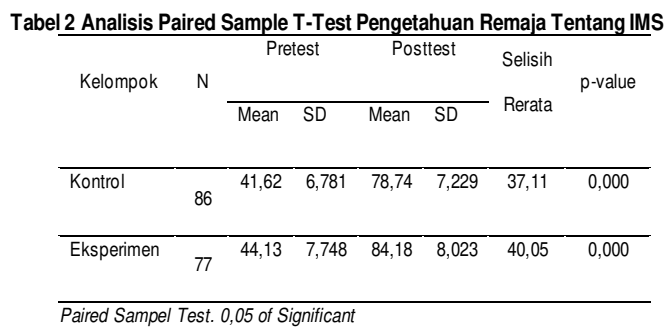

Berdasarkan tabel 2 diketahui bahwa hasil analisis paired sample t-test menunjukkan ada peningkatan pengetahuan pada kelompok eksperimen sebesar 84,18 (posttest) dibanding dari hasil sebelumnya yaitu sebesar 44,13 (pretest) yang artinya bahwa ada peningkatan pengetahuan setelah diberikan intervensi dengan media audiovisual. Uji statistik menunjukkan adanya peningkatan pengetahuan remaja tentang infeksi menular seksual, hal tersebut dapat dilihat pada taraf signifikan sebesar $0.000(\mathrm{p}<0,05)$.

Demikian pula hasil analisis paired sample t-test pada kelompok kontrol menunjukkan ada peningkatan pengetahuan sebesar 78,74 (posttest) dibanding dari hasil sebelumnya yaitu sebesar 41,62 (pretest) yang artinya bahwa ada peningkatan pengetahuan setelah diberikan intervensi dengan media leaflet. Uji statistik menunjukkan adanya peningkatan pengetahuan remaja tentang infeksi menular seksual, hal tersebut dapat dilihat pada taraf signifikan sebesar $0,000(\mathrm{p}<0,05)$.

3. Analisis Perbedaan Selisih Peningkatan Pengetahuan Remaja Tentang Infeksi Menular Seksual Antara Kelompok Eksperimen dan Kelompok Kontrol

Tabel 3. Perbedaan Selisih Peningkatan Pengetahuan Remaja Tentang Infeksi Menular Seksual Antara Kelompok Eksperimen dan Kelompok Kontrol

\begin{tabular}{lcccc}
\hline Kelompok & $\mathrm{N}$ & Mean & $\mathrm{SD}$ & $\mathrm{p}$-value \\
\hline Kontrol & 86 & 37,11 & 5.494 & \multirow{2}{*}{0,000} \\
Eksperimen & 77 & 40,05 & 2,715 & \\
\hline \multicolumn{7}{l}{ Independent Sampel Test. 0,05 of Significant }
\end{tabular}

Berdasarkan tabel 3 dapat ditunjukkan selisih pengetahuan kelompok kontrol sebesar 37,11 dan kelompok eksperimen sebesar 40,05. Berdasarkan uji independent sample t-test diketahui perbedaan yang bermakna antara dua kelompok tersebut, hal ini dapat dilihat dari taraf signifikan sebesar $0,000(\mathrm{p}<0,05)$. 
4. Pengaruh Penyuluhan dengan Media Audiovisual Terhadap Pengetahuan Remaja Tentang Infeksi Menular Seksual.

Berdasarkan analisis paired sample t-test pada Tabel 2 dapat ditunjukkan bahwa pengetahuan responden pada kelompok eksperimen sebelum diberikan intervensi menunjukkan hasil sebesar 44,13 Setelah dilakukan intervensi pada kelompok eksperimen dengan memberikan penyuluhan dengan media audiovisual, pengetahuan responden meningkat menjadi 84,18 dengan $p$-value $=0,000$ $<0,05$. Hal ini menunjukkan adanya perbedaan bermakna antara nilai pengetahuan pretest dan posttest pada kelompok eksperimen, sehingga media audiovisual efektif meningkatkan pengetahuan responden.

Hasil penelitian ini menegaskan bahwa pemberian penyuluhan dengan media audiovisual pada siswa dapat memberikan informasi yang jauh lebih efektif dan lebih dimengerti oleh siswa, sehingga nilai sebelum diberikan penyuluhan kesehatan dan setelah diberikan penyuluhan kesehatan mengalami peningkatan pengetahuan pada siswa. Melihat berbagai dampak akibat kurangnya pengetahuan tentang kesehatan reproduksi, maka perlu berbagai upaya untuk membantu remaja agar memahami dan menyadari tentang kesehatan reproduksi, serta bertanggungjawab dengan masalah kesehatan reproduksinya. Sebagian langkah awal pencegahan, peningkatan pengetahuan remaja tentang kesehatan reproduksi harus ditunjang dengan penyuluhan tentang penyebab dan konsekuensi perilaku seks, apa yang harus dilakukan dan dilengkapi dengan informasi mengenai sarana pelayanan yang bersedia menolong seandainya telah terjadi kehamilan yang tidak dikehendaki atau tertular infeksi saluran kemih/ infeksi menular seksual. Belajar dengan menggunakan media audiovisual lebih mampu meningkatkan pengetahuan siswa.

Hal ini sejalan dengan penelitian yang dilakukan oleh Nadeak, Agrina \& Misrawati, (2017), tentang efektifitas promosi kesehatan melalui media audiovisual mengenai HIV/AIDS terhadap peningkatan pengetahuan remaja tentang HIV/AIDS, hasil penelitian menunjukkan ada peningkatan yang signifikan dalam kelompok ekperimen dengan nilai $\mathrm{p}(0,000)<\alpha(0,05)$. Artinya promosi kesehatan dengan menggunakan audiovisual efektif untuk meningkatkan pengetahuan remaja tentang HIV/AIDS.

Penelitian lain yang dilakukan Pragita \& Purwandari, (2017) yang berjudul "Pengaruh Pendidikan Kesehatan Metode Stratagem dengan Media Audiovisual terhadap Pengetahuan Kesehatan Reproduksi Remaja". Penelitian ini melibatkan 15 orang sebagai kelompok eksperiment, dan 15 orang sebagai kelompok kontrol dengan menggunakan proporsional stratified random sampling. Hasil data yang p nilai 0,014 dan $0,016 \quad(\alpha<0,05)$. Hasil penelitian ini menyatakan bahwa ada pengaruh yang signifikan antara pendidikan kesehatan melalui metode stratagem media audiovisual pada pengetahuan remaja mengenai kesehatan reproduksi dan terdapat perbedaan pengaruh dalam pendidikan kesehatan melalui metode stratagem media audiovisual dan metode konvensional ceramah. Kesimpulan dari penelitian ini bahwa metode straragem media audiovisual mampu meingkatkan pengetahuan remaja tentang kesehatan reproduksi. Sama halnya dengan penelitian yang sekarang, yaitu penyuluhan dengan menggunakan media audiovisual dengan nilai signifikan sebesar 0,000 $(\mathrm{p}<0,05)$, sehingga terbukti bahwa media audiovisual dapat meningkatkan pengetahuan terhadap remaja dan pada penelitian ini nilai signifikan lebih tinggi jika dibandingkan dengan penelitian yang dilakukan sebelumnya oleh Pragita \& Purwandari, (2017).

Pengetahuan adalah hasil informasi yang kemudian diperhatikan, dimengerti, dan diingat (Notoatmojo, 2010). Informasi dapat bermacammacam bentuknya baik pendidikan formal maupun informal, seperti membaca surat kabar, mendengar radio, menonton TV, percakapan sehari-hari, dan pengalaman hidup lainnya. Pengetahuan berupa segala sesuatu yang diketahui dan berkenaan dengan hasil. Pengetahuan merupakan hasil setelah orang melakukan penginderaan terhadap suatu objek tertentu, penginderaan terjadi melalui pancaindera manusia, yaitu penglihatan, pendengaran, penciuman, rasa, dan raba. Sebagian besar pengetahuan manusia diperoleh melalui mata dan telinga. Pengetahuan merupakan hasil tahu dari seseorang setelah melakukan penginderaan baik indra penglihatan, pendengaran, penciuman maupun raba. Notoatmodjo, (2012) menyatakan bahwa pengetahuan ini terjadi setelah orang melakukan pengindraan terhadap suatu objek tertentu. Pengetahuan adalah hasil dari mengingat sesuatu hal yang dapat diperoleh oleh seseorang secara alami atau mendapat intervensi baik langsung maupun tidak langsung.

5. Pengaruh Penyuluhan dengan Media Leaflet Terhadap Pengetahuan Remaja Tentang Infeksi Menular Seksual.

Berdasarkan analisis paired sample t-test pada Tabel 2 dapat ditunjukkan bahwa pengetahuan responden pada kelompok kontrol sebelum diberikan intervensi menunjukkan hasil sebesar 41,62 Setelah dilakukan intervensi pada kelompok eksperimen dengan memberikan penyuluhan dengan media audiovisual, pengetahuan responden meningkat menjadi 78,74 dengan pvalue $=0,000<0,05$. Hal ini menunjukkan adanya 
perbedaan bermakna antara nilai pengetahuan pretest dan posttest pada kelompok kontrol, sehingga leaflet efektif meningkatkan pengetahuan responden, namun peningkatan pada kelompok eksperimen, lebih besar dibanding kelompok kontrol.

Hasil penelitan dari Septianingrum \& afiyah, (2018) menjelaskan bahwa penyuluhan kesehatan yang diberikan leaflet efektif meningkatkan pengetahuan, dimana penelitian ini juga sejalan dengan penelitian Syaiful dan Aristantia, (2016). Dimana rata-rata nilai sebelum diberikan leaflet dan sesudah diberikan leaflet yaitu 1,397 dengan $p$-value 0,001 . Sama halnya dengan penelitian yang sekarang, yaitu penyuluhan dengan menggunakan media leaflet, dengan nilai signifikan $\mathrm{p}=0,000$, sehingga terbukti bahwa media leaflet dapat meningkatkan pengetahuan remaja dan pada penelitian ini nilai signifikan lebih tinggi dari pada penelitian yang dilakukan sebelumnya oleh Septianingrum \& afiyah (2017).

Media penyuluhan kesehatan yang digunakan berpengaruh terhadap penyampaian informasi. Leaflet merupakan media yang digunakan dalam penyampaian informasi yang digunakan peneliti dalam memberikan penyuluhan kesehatan pada kelompok kontrol. Menurut Suiraoko \& Supariasa, (2012), leaflet adalah selembar kertas yang dilipat-lipat, beberapa gambar mengenai suatu topik untuk sasaran dan tujuan tertentu. Agar terlihat menarik biasanya leaflet didesain dengan ilustrasi dan menggunakan bahasa sederhana yang mudah dipahami.

Adapun kelebihan menggunakan leaflet adalah sasaran dapat menyesuaikan dan belajar mandiri serta praktis karena mengurangi kebutuhan mencatat, sasaran dapat melihat isinya disaat santai. Informasi dapat dibaca dan didiskusikan antar anggota kelompok serta dapat juga memberikan informasi secara detail, mudah dibuat, diperbanyak dan disesuaikan dengan kelompok sasaran (Fauziah, Maesaroh, Sulistyarini, 2017)

6. Perbedaan pengaruh penyuluhan dengan menggunakan media audiovisual dan leaflet terhadap pengetahuan remaja tentang Infeksi Menular Seksual.

Pada hasil uji independent t-test penelitian ini, berdasarkan tabel 3 terdapat selisih peningkatan pengetahuan antara kelompok eksperimen $(40,05)$ dan kelompok kontrol $(37,11)$ dengan taraf signifikan sebesar $0,000 \quad(\mathrm{p}<0,05)$. Sehingga penggunaan media audiovisual dapat dikatakan lebih berpengaruh dibanding media leaflet dalam meningkatkan pengetahuan remaja tentang infeksi menular seksual.
Hasil penelitian sebelumnya dengan menggunakan media audiovisual dan leaflet yang dilakukan oleh Tindaon (2018) tentang pengaruh komunikasi, informasi dan edukasi (KIE) melalui media leaflet dan video terhadap pengetahuan dan sikap remaja tentang paparan pornografi di SMPN 1 Sidamanik. Hasil penelitian menunjukkan adanya perbedaan perubahan pengetahuan tentang pornografi antara leaflet $(7,33)$ dan video $(8,40)$ dengan nilai $\mathrm{p}=0,000$ dimana perubahan pengetahuan lebih besar pada video artinya media video lebih efektif untuk merubah pengetahuan dibanding media leaflet.

Hasil ini sejalan dengan hasil penelitian yang dikemukakan oleh Fauziah tentang lemahnya leaflet itu sendiri yang tidak tahan lama dan mudah hilang, leaflet akan menjadi percuma jika responden tidak diikut sertakan secara aktif (Fauziah, Maesaroh, Sulistyarini, 2017)

\section{KESIMPULAN DAN REKOMENDASI}

Pemberian penyuluhan dengan media audiovisual dan leaflet dapat meningkatkan secara signifikan tingkat pengetahuan remaja tentang infeksi menular seksual. Namun Pemberian penyuluhan dengan media audiovisual lebih baik dibandingkan menggunakan media leaflet.

Pemberian penyuluhan dengan media audiovisual dapat digunakan sebagai salah satu alternatif media penyuluhan yang dapat digunakan untuk meningkatkan pengetahuan remaja tentang infeksi menular seksual. Diperlukan penelitian lanjutan untuk mengetahui resistensi pengetahuan tersebut dengan pemanfaatan media audiovisual.

\section{REFERENSI}

Aritonang. (2015). Hubungan Pengetahuan Dan Sikap Tentang Kesehatan Reproduksi Dengan Perilaku Seks Pranikah Pada Remaja Usia (15-17 Tahun) Di SMK Yadika 13 Tambun, Bekasi', Jurnal Ilmiah WIDYA, pp. 6-67. doi:10.1002/10970142(19840501)53:9<1923 ::AID-CNCR2820530919>3.0.CO;2-M.

Fauziah, Maesaroh, Sulistyarini. 2017. Penggunaan Leaflet Terhadap Peningkatan Pengetahuan Tentang Pemeriksaan Payudara Sendiri (SADARI). Gaster Vol. XV No. 2 Agustus 2017. http://jurnal.aiskauniversity.ac.id/index.php/gaster/article/view $\underline{1207}$

Kemenkes (2012) Laporan Akhir Riset Fasilitas Kesehatan 2011, Badan penelitian dan pengembagan Kesehatan Kemenkes RI. doi: 10.1136/bmjqs-2011-000308. 
Kemenkes RI (2017) Profil Kesehatan Indonesia 2016, Kementerian Kesehatan Republik Indonesia.

Mamarodia, Kandou, dan Suling. (2017). Hubungan antara Pengetahuan, Sikap, Peran orangtua dan Ketaatan Beragama dengan Tindakan Pencegahan Penyakit Menular Seksual Pada Siswa di SMA Dharma Wanita Pineleng. Community Health Journal 2017

Meidiana, R., Simbolon, D. and Wahyudi, A. (2018) 'Pengaruh Edukasi melalui Media Audio Visual terhadap Pengetahuan dan Sikap Remaja Overweight', 9(November), pp. 478484.

Nadeak, D. N., Agrina and Misrawati (2017) Efektivitas Promosi Kesehatan Melalui Media Audiovisual Mengenai HIV/AIDS Terhadap Peningkatan Pengetahuan Remaja Tentang HIV/AIDS.

Notoatmodjo, S. (2010) Promosi Kesehatan Teori dan Aplikasi. Jakarta: PT. Rineka Cipta.

Notoatmodjo, S. (2012) Kesehatan Masyarakat Ilmu dan Seni. Jakarta: Rineka Cipta.

Pangaribuan, S. M. and Mardiah, W. (2018) 'Gambaran Tingkat Pengetahuan Wanita Pekerja Seks Komersial Tentang Infeksi Menular Seksual', Jurnal Pendidikan Keperawatan Indonesia, 3(2), p. 175 . doi: 10.17509/jpki.v3i2.9423.

Pragita, Purwandari, Sulistyorini. 2017. Pengaruh Pendidikan Kesehatan Metode Stratagem dengan Media Audiovisual Terhadap Pengetahuan Kesehatan Reproduksi Remaja. The Indonesian Journal of Health Science. http://jurnal.unmuhjember.ac.id/index.php/TI JHS/article/view/1521

Rahayu, S., Suciawati, A., \& Indrayani, T. (2021). Pengaruh Edukasi Tentang Kesehatan Reproduksi Remaja Terhadap Pengetahuan Dan Sikap Seksual Pranikah Di Smp Yayasan Pendidikan Cisarua Bogor. Journal for Quality in Women's Health,4(1), 1-6. https://doi.org/10.30994/jqwh.v4i1.101

Rahmi, Gustini, Puspita (2015). Pengetahuan Siswa Kelas XI Tentang Penyakit Menular Seksual. Jurnal Pendidikan Keperawatan Indonesia. $\begin{array}{lllll}\text { Vol } & 1 & \text { No } & 2 . & 2015 .\end{array}$ https://ejournal.upi.edu/index.php/JPKI/articl e/view/9748

Septianingrum, Y., \& Afiyah, R. K. (2018). Penyuluhan Deteksi Dini Kanker Payudara di Pondok Pesantren Qomarudin Bungah Gresik. Community Development Journal, 1(2). https://doi.org/10.33086/cdj.v1i2.348
Suiraoka dan Supariasa. 2012. Media Pendidikan Kesehatan. Yogyakarta: Graha Ilmu

Syaiful \& Aristantia. 2016. Pendidikan Kesehatan Pemeriksaan Payudara Sendiri Terhadap Perilaku SADARI pada Remaja. Journals of Ners Community. Vol 7 No 2. http://journal.aakdelimahusadagresik.ac.id/in dex.php/JNC/article/view/205

Zatalini, dan Wulandari. (2018). Pengaruh Penyuluhan dengan Metode Diskusi, Poster dan Video Terhadap Tingkat Pengetahuan Tentang Penyakit Menular Seksual Pada Anak Jalanan Kota Semarang (Studi Kasus di Rumah Pintar Bang Jo). Laporan Hasil Penelitian Karya Tulis Ilmiah Program Pendidikan Sarjana Kedokteran Universitas Diponegoro. http://eprints.undip.ac.id/61942/

Tindaon. 2018. Pengaruh Komunikasi Informasi dan Edukasi Melalui Media Leaflet dan Video Terhadap Pengetahuan dan Sikap Remaja Tentang Paparan Pornografi di SMP Negeri 1 Sidamanik Kec Sidamanik. Kabupaten Simanlungun Tahun 2016. Jurnal Ilmu Penelitian Kesehatan. Vol 3 No 1. 